\title{
Study on the Pattern of Antibiotic Use Including the Resistance Episodes in Bangladesh
}

\author{
M. Shazzadul Islam, K. M. Yasif Kayes Sikdar, A. S. M. Monjur-Al-Hossain \\ and A. B. M. Faroque
}

Department of Pharmaceutical Technology, University of Dhaka, Dhaka-1000, Bangladesh

(Received: September 12, 2018; Accepted: May 22, 2019; Published (Web.): October 5, 2019)

\begin{abstract}
Antibiotic resistance is currently one of the biggest challenges faced by the health professionals worldwide. Bacteria are becoming resistant to commonly used antibiotics and various factors have been identified that are responsible for the resistance. Factors like poor quality of antibiotic products, unethical marketing practices by pharmaceutical companies, irrational use of antibiotics by the physicians and patient incompliance are also common in Bangladesh. To carry out this study, firstly the extent of antibiotic resistance was evaluated by collecting clinical isolates from various diagnostic centers of Dhaka City and conducting antibiotic susceptibility test against commonly used antibiotics. The product quality was evaluated by collecting antibiotic products of different generics from various locations around Bangladesh and then performing drug content assay by HPLC method. Finally, to evaluate patient incompliance, a questionnaire-based survey was conducted on patients who took or had taken antibiotics recently and the collected data was analyzed statistically. The result of the investigation reveals that more than $80 \%$ of the collected Escherichia coli (E. coli) isolates were resistant to currently used antibiotics like, azithromycin, ciprofloxacin, amoxicillin, cefixime, cefuroxime, and moxifloxacin. Similar holds true for the collected Staphylococcus aureus (S. aureus) isolates. The product quality in terms of drug content and dissolution was good for most products irrespective of whether the manufacturer had a high market value or not. Patients survey revealed that $82 \%$ discontinued antibiotic therapy was due to carelessness $(49 \%)$, a false sense of cure (36\%) and high cost (15\%).
\end{abstract}

Key words: Antibiotic resistance, antibiotic susceptibility test, drug content, questionnaire, patient survey.

\section{INTRODUCTION}

Antibiotic resistance is an observable fact where infectious bacteria are no longer susceptible to previously effective antibiotics. Currently over seven million people die every year worldwide due to antibiotic resistance. According to the Centers for Disease Control and Prevention (CDC), each year in the United States, at least 2 million people are infected with antibiotic resistant bacteria and as a result of these infections each year at least 23,000 people are leading to death. ${ }^{1}$ Researchers estimate that this rate will increase further to 10 million people by 2050. In Bangladesh, it is opined that $55.7 \%$ of city dwellers are locked with antibiotic resistant microorganisms. ${ }^{2}$

Correspondence to: A B M Faroque

Phone: +88029661900-73; Cell: 01830002826

Email: abmfaroque@yahoo.com

Dhaka Univ. J. Pharm. Sci. 18(2): 135-143, 2019 (December) DOI: https://doi.org/10.3329/dujps.v18i2.43255
Discovery of antibiotics actually initiated a new era in the clinical practice of infectious diseases. Nonetheless, that period possibly is arriving at an end with a dreadful post-antibiotic era where bacteria cannot again be killed or hindered by antibiotics. Such dread is originated from the fact that bacteria have quickly created resistance from the vast majority of the presently accessible antibiotic items in the market. The two most dangerous superbugs are methicillin-resistant Staphylococcus aureus (MRSA) and extended spectrum beta-lactamase-producing Enterobacteriaceae (ESBL). The outcome provides evidence that infection control can be highly effective at limiting the spread of MRSA and the patients infected with ESBL-producing organisms are at risk for poor outcome if they are treated with antibacterial to which the organism exhibits highlevel of resistance. 
In various countries, some common factors have been identified that contributes to the development of antibiotic resistance. These include inappropriate prescribing of antibiotics, patient incompliance with antibiotic therapy, less than optimal manufacturing facilities and policies etc.

Resistance may start through manufacturing. Medicines manufactured with insufficient active pharmaceutical ingredient (API), either deliberately or as the result of a production error, will clearly be sub-therapeutic. ${ }^{3}$ Some of the active ingredients are more likely to degrade than others, and degradation in most cases leads to a loss of potency. In addition, degradation of excipients may affect the way the medicine dissolves as well as thus reduce the bioavailability of the medicine to the patient. The amount of active ingredient delivered to the bloodstream may be reduced by poor formulation, including the use of substandard excipients that affect the release and bioavailability pattern. Even the correct amount of medicine releasing too quickly or too slowly, can promote the development or replication of resistant bacteria. ${ }^{3}$

Alongside assembling generous amounts of antibiotics discharged from polluted industrial facilities, which join with spillover from homesteads and human waste in water bodies and sewage treatment plants, give an ideal rearing ground for microscopic organisms. Bacteria in these conditions can share or trade hereditary material, something which can likewise happen between various bacterial species. An investigation looking at pharmaceutical contamination in exceptionally populated Asian nations including China, India, Bangladesh and Pakistan depicted "serious threats to the environment" presented by the efforts to manufacture pharmaceutical products at a low-cost in those countries. $^{4}$

Bangladesh along with many developing countries allows dispensing of antibiotics without any prescription which leads to self-medication. A survey in Rajbari district found that 1,00,000 antibiotic doses had been dispensed in a month without any prescription. ${ }^{5}$ Another study depicts that on an average, $92 \%$ of medications dispensed from the pharmacies were without any prescription. ${ }^{6}$ Currently most of the drugs in Bangladesh are prescribed or sold by non-qualified or relatively less qualified health workers. ${ }^{7}$ Moreover, it was found that patients discontinue their medicine intake with their own will and they do not maintain any follow up visit with their physicians. Carelessness, unawareness and financial reasons were also identified behind discontinuation of medication. ${ }^{8}$

Incorrectly prescribed and overused antibiotics contribute to the promotion of resistant bacteria. ${ }^{8}$ Often multiple brands of the same generic are available where some brands may be of inferior quality. $^{9}$ The antibiotic prescribing procedure in Bangladesh is not perfect as beforehand the pathogens are not identified and their sensitivity is also not checked. ${ }^{10}$

In our country, unethical drug promotion and marketing of substandard and unnecessary drugs is very much frequent. Quality and efficacy of locally manufactured antimicrobial drugs are also largely unregulated. A medical practitioner can prescribe medicines for common cold to cancer. Moreover, polypharmacy is very common among the rural medical practitioners where antibiotics and vitamins are prescribed very widely. ${ }^{11}$ Currently, drug companies are the only organizations in Bangladesh to provide information to the health professionals and very often these information are not appropriate scientific information. ${ }^{12}$ Excessive and inappropriate use of antibiotics also adds an unnecessary economic burden to healthcare system and coincides with an increase in drug-resistant pathogens, which has resulted in the use of more expensive and toxic higher drugs.

Hence, a systematic study was undertaken to identify the extent of antibiotic resistance that is being faced in the clinical practice in Bangladesh and to evaluate if antibiotic products maintain proper quality, whether resistance is associated with poor product quality, the extent of self-medication, patient's incompliance and whether these may be 
associated with this phenomenon of increased microbial resistance.

\section{MATERIALS AND METHODS}

Reagents and apparatus. A number of reagents and apparatus were used from the Pharmaceutical Technology Lab and Biomedical Research Centre, University of Dhaka.

For susceptibility test, Tryptic Soy Broth, agar brought from UK, shaker incubator from Heidolph, Germany and a regular incubator were used.

In evaluation of product quality (e.g. drug content \& dissolution) high-performance liquid chromatography (HPLC) from Waters, USA, $\mathrm{pH}$ meter, syringe filter $(0.22 \mu \mathrm{m}$ pore size $)$, HPLC vial and other apparatus were obtained from Pharmaceutical Technology Lab, University of Dhaka. Methanol, acetonitrile, tetrabutyl-ammonium hydroxide, ammonium dihydrogen orthophosphate, HPLC grade water, acetic acid, sodium acetate and sodium hydroxide were bought from Merck, Germany. Dissolution apparatus USP Type I, dissolution apparatus USP Type II, UV-Visible spectrophotometer (Shimadzu, Japan), potassium phosphate buffer, hydrochloric acid, sodium phosphate buffer, sodium hydroxide and distilled water were used which were obtained from the Pharmaceutical Technology Lab and Biomedical Research Centre, University of Dhaka.

Investigation of antimicrobial susceptibility of clinical isolates in Bangladesh. For the susceptibility test firstly, clinical isolates were collected from Popular Diagnostic Center and Medinova Diagnostic Center, Dhanmondi. The test tubes containing isolates collected from the diagnostic centers were immediately transferred to an icebox and bought to laboratory for preservation. Mineral oil was used to preserve the isolates and finally was poured over the slant in such a way that mineral oil remains at least $1 \mathrm{~cm}$ above the top of the slant.

Confirmed clinical strains of $E$. coli and $S$. aureus were tested against various selected antibiotics (commonly used) for the determination of their resistance profile. This investigation was done according to the Clinical Laboratory Standards Institute (CLSI), European Committee on Antibiotic Susceptibility Testing (EUCAST), and British Society for Antimicrobial Chemotherapy (BSAC) guidelines. The investigation was carried out by using the Kirby-Bauer Disc Diffusion assay method. ${ }^{13}$

Investigation into product quality. To evaluate the quality of the drug products, firstly the product was made into a fine powder by crushing in a mortar. Then the mobile phase was prepared according to table $1^{14}$ and it was filtered through a syringe filter $(0.22 \mu \mathrm{m})$ in order to remove any particle that may damage the HPLC column. Then a specific amount of powder containing the drug was weighed carefully and dissolved in appropriate volume of the mobile phase. ${ }^{12}$ After vigorous shaking, the solution was first filtered by normal filter paper to remove any undissolved particle. Then it was further filtered through the syringe filter $(0.22 \mu \mathrm{m})$ into the HPLC vial. The HPLC vials were thus prepared and placed inside the auto sampler unit of the HPLC.

For each product, triplicate assays performed. All the columns, mobile phase compositions, $\mathrm{pH}$ of the mobile phases, flow rates, detection wavelengths etc. varied based on the generics.

In order to evaluate the release pattern of drug products dissolution tests were performed. Appropriate dissolution apparatus (USP Type I and II as required) were used. The dissolution media was also prepared to the recommended $\mathrm{pH}$. Then $900 \mathrm{ml}$ of the dissolution medium were taken in the appropriate vessel and the temperature was regulated to $37 \pm 1^{\circ} \mathrm{C}$. Rotation of the paddle or the basket was also kept at the prescribed condition in table $2 .^{14}$

An aliquot of $5 \mathrm{ml}$ samples from the dissolution medium was taken out at specific time interval followed by diluting appropriately. Afterwards, absorbance of the diluted solution was measured using an UV-Visible spectrophotometer at the specified wavelength. A calibration curve was prepared for each drug and using the curve dissolution of drug was measured. 
Investigation on patient incompliance. After acquainted with the literature review on this subject a hypothesis was formed focusing on the main information needed to test the hypothesis. A plan of analysis was drawn which helped to identify the statistical tests. A questionnaire was prepared by knowing the education and occupation level of the study population, cultural background, language proficiency and special sensitivities which are crucial at this stage. Based on the survey plan some patients from government and private hospitals were selected.
They were selected differently to identify the psychological shift. Financial status could be another cause of antibiotic resistance and that's why patients from two different classes of hospitals were selected. In this regard, patients' data were collected from posh hospitals of Dhaka city especially from Labaid, Popular, Green Life etc. hospitals as well as from periphery bases of Comilla, Barisal and Sylhet. Those patients were selected randomly and they were aware of the survey for the sake of getting proper data and their privacy was maintained carefully.

Table 1. Specifications of different parameters of HPLC for individual antibiotics.

\begin{tabular}{|c|c|}
\hline Drug & Specifications of different parameters of HPLC for individual antibiotics \\
\hline Azithromycin & $\begin{array}{l}50 \mu \mathrm{l} \text { of the drug sample was passed through a column (Xterra, } 4.6 \mathrm{~mm} \times 25 \mathrm{~cm} ; 5 \mu \text { ) with a flow rate } 1.5 \mathrm{ml} / \mathrm{min} \\
\text { having a mobile phase [Solution A: dibasic potassium phosphate and sodium 1-octanesulfonate was dissolved in } \\
\text { water and } \mathrm{pH} \text { was adjusted with phosphoric acid to } 8.20 \pm 0.05 \text {. Mobile phase: acetonitrilie, solution-A, and } \\
\text { methanol }(450: 400: 150) \text { ]. Elute was detected through UV detector at } 210 \mathrm{~nm} \text { with a run time of } 10 \text { minutes. }\end{array}$ \\
\hline Ciprofloxacin & $\begin{array}{l}\left.5 \mu \mathrm{l} \text { of the drug sample was passed through a column (X-bridge, } \mathrm{C}_{18}, 4.6 \times 250 \mathrm{~mm}, 5 \mu\right) \text { with a flow rate of } 1.5 \\
\mathrm{ml} / \mathrm{min} \text { having a mobile phase [Buffer: orthrophosphoric acid }(85 \%) \text { was taken with } 1.8 \mathrm{~L} \text { water and } \mathrm{pH} \text { was adjusted } \\
\text { to } 3 \pm 0.1 \text { with triethylamine. Mobile phase: a mixture of } 13 \text { volumes of acetonitrile and } 87 \text { volumes of buffer } \\
(13: 87) \text { ]. Elute was detected through UV detector at } 278 \mathrm{~nm} \text { with a run time of } 9 \text { minutes. }\end{array}$ \\
\hline Amoxicillin & $\begin{array}{l}50 \mu \mathrm{l} \text { of the drug sample was passed through a column (Hypersil } 5 \text { ODS, USP type } \mathrm{L} 1, \mathrm{C}_{18}, 4.6 \mathrm{~mm} \times 250 \mathrm{~mm} \text { ) with } \\
\text { a flow rate } 1 \mathrm{ml} / \mathrm{min} \text { having a mobile phase [Buffer: potassium dihydrogen orthophosphate }(25 \% \mathrm{v} / \mathrm{v}, 0.2 \mathrm{M} \text { ) was } \\
\text { dissolved in } 900 \mathrm{ml} \text { water and pH was adjusted to } 5.0 \pm 0.1 \text { with } 2 \mathrm{M} \text { sodium hydroxide. Mobile phase A: mixer of } \\
\text { acetonitrile and buffer solution in 1:99 ratio. Mobile phase B: mixer of acetonitrile and buffer solution in } 20: 80 \text { ratio]. } \\
\text { Elute was detected through UV detector at } 272 \mathrm{~nm} \text { with a run time of } 12 \text { minutes. }\end{array}$ \\
\hline Cefixime & $\begin{array}{l}10 \mu 1 \text { of the drug sample was passed through a column (USP1, } 12.5 \mathrm{~cm} \mathrm{x} 4.6 \mathrm{~mm} \text { ) with a flow rate } 1 \mathrm{ml} / \mathrm{min} \text { having a } \\
\text { mobile phase [Acetonitrile: } 0.4 \mathrm{M} \text { tetrabutyl ammonium hydroxide }(12.5 \%)(25: 75) \text { ] of } \mathrm{pH} 6.5 \pm 0.05 \text {. Elute was } \\
\text { detected through UV detector at } 254 \mathrm{~nm} \text { with a run time of } 15 \text { minutes. }\end{array}$ \\
\hline Cefuroxime & $\begin{array}{l}10 \mu \mathrm{l} \text { of the drug sample was passed through a column (USP13, } 25 \mathrm{~cm} \times 4.6 \mathrm{~mm}) \text { with a flow rate } 1.5 \mathrm{ml} / \mathrm{min} \text { having } \\
\text { a mobile phase [0.2 M monabasic ammonium phosphate: methanol (62:38)]. Elute was detected through UV detector } \\
\text { at } 278 \mathrm{~nm} \text { with a run time of } 18 \text { minutes. }\end{array}$ \\
\hline Moxifloxacin & $\begin{array}{l}10 \mu \mathrm{l} \text { of the drug sample was passed through a column (Luna C18, } 5 \mu \mathrm{m}, 250 \times 4.6 \mathrm{~mm} \text { ) with a flow rate } 1 \mathrm{ml} / \mathrm{min} \\
\text { having a mobile phase [methanol and buffer, ( } 45: 55) \text { of } \mathrm{pH} 6.3 \pm 0.4 \text {. Elute was detected through UV detector at } 293 \\
\mathrm{~nm} \text { with a run time of } 10 \text { minutes. }\end{array}$ \\
\hline
\end{tabular}

Table 2. Specifications of different parameters of dissolution test for individual antibiotics.

\begin{tabular}{lllcc}
\hline Drug & Dissolution media & Dissolution apparatus & $\begin{array}{c}\text { RPM of the paddle/ } \\
\text { basket }\end{array}$ & $\begin{array}{c}\text { Wavelength of measurement } \\
(\mathrm{nm})\end{array}$ \\
\hline Azithromycin & Sodium phosphate buffer & USP Type II & 100 & 210 \\
Ciprofloxacin & $0.01 \mathrm{~N} \mathrm{HCl}$ & USP Type II & 50 & 278 \\
Amoxicillin & Phosphate buffer & USP Type II & 75 & 272 \\
Cefixime & Potassium phosphate buffer & USP Type I & 100 & 288 \\
Cefuroxime & $0.07 \mathrm{~N} \mathrm{HCl}$ & USP Type II & 55 & 278 \\
Moxifloxacin & $0.1 \mathrm{~N} \mathrm{HCL}$ & USP Type II & 50 & 295 \\
\hline
\end{tabular}




\section{RESULTS AND DISCUSSION}

Antibacterial susceptibility of the clinical isolates collected from various diagnostic centers across Dhaka City was evaluated by Kirby-Bauer Disc Diffusion assay as stated previously. The data showed that antibiotic resistance is prevalent in Bangladesh, at least for E. coli and S. aureus clinical isolates. Result of the investigation revealed that more than $80 \%$ of the collected E. coli isolates were resistant to azithromycin, ciprofloxacin, amoxicillin, cefixime, cefuroxime and moxifloxacin and that was similarly true for the collected S. aureus isolates. Surprisingly, among the antibiotics, no one was effective against E. coli and S. aureus was $88 \%$ sensitive to amoxicillin only. Results are tabulated and showed in the table 3 .

The data showed that most products which were evaluated in this study complied to the official limits for drug content and drug dissolution. Among 32 samples, only three 3 samples did not comply to the range of drug content, whereas among 28 samples, only two 2 samples did not comply to the range of drug dissolution test. These results are given in table 4 and 5. Hence, for most products, the quality was acceptable or good. However, there were few products, which provided good result for drug content assay but failed the drug in dissolution test.

Table 3. Summary of antibacterial susceptibility of the collected clinical isolates against selected antibiotics.

\begin{tabular}{|c|c|c|c|c|c|c|}
\hline \multirow[t]{3}{*}{ Antibiotics } & \multicolumn{3}{|c|}{ Escherichia coli $(\mathrm{n}=40)$} & \multicolumn{3}{|c|}{ Staphylococcus aureus $(\mathrm{n}=10)$} \\
\hline & \multicolumn{6}{|c|}{$(\%)$} \\
\hline & Resistant & $\begin{array}{c}\text { Moderate } \\
\text { sensitive }\end{array}$ & Sensitive & Resistant & $\begin{array}{c}\text { Moderate } \\
\text { sensitive }\end{array}$ & Sensitive \\
\hline Azithromycin (AZM) & $98 \%$ & $0 \%$ & $2 \%$ & $50 \%$ & $0 \%$ & $50 \%$ \\
\hline Ciprofloxacin (CIP) & $74 \%$ & $2 \%$ & $24 \%$ & $88 \%$ & $13 \%$ & $0 \%$ \\
\hline Amoxicillin (AMX) & $95 \%$ & $0 \%$ & $5 \%$ & $13 \%$ & $0 \%$ & $88 \%$ \\
\hline Cefixime (CFM) & $79 \%$ & $0 \%$ & $21 \%$ & $100 \%$ & $0 \%$ & $0 \%$ \\
\hline Cefuroxime (CXM) & $81 \%$ & $7 \%$ & $12 \%$ & $63 \%$ & $0 \%$ & $38 \%$ \\
\hline Moxifloxacin (MFX) & $88 \%$ & $0 \%$ & $12 \%$ & $38 \%$ & $13 \%$ & $50 \%$ \\
\hline
\end{tabular}

Table 4. Percentage of sample recovery through HPLC.

\begin{tabular}{lcccccc}
\hline Generic & Company & Brand & $\begin{array}{c}\text { Strength } \\
(\mathrm{mg})\end{array}$ & Assay Limit (USP) & $\begin{array}{c}\text { Result } \\
\text { Result } \\
(\%)\end{array}$ \\
\hline Azithromycin & C-1 & B-1 & 500 & $450-550 \mathrm{mg} / \mathrm{Tab}$ & 500.6 & 100.12 \\
& C-2 & B-2 & & $(90-110 \%)$ & 449.6 & 89.92 \\
& C-3 & B-3 & & & 447.3 & 89.46 \\
& C-4 & B-4 & & & 482.1 & 96.42 \\
& C-5 & B-5 & & & 500.1 & 100.02 \\
& C-6 & B-6 & & & 501 & 100.20 \\
\hline Ciprofloxacin & C-1 & B-1 & 500 & $475-525 \mathrm{mg} / \mathrm{Tab}$ & 488.47 & 97.69 \\
& C-2 & B-2 & & $(95-105 \%)$ & 486.91 & 97.38 \\
& C-3 & B-3 & & & 489.35 & 97.87 \\
& C-4 & B-4 & & & 340.1 & 68.02 \\
& C-5 & B-5 & & & 502.53 & 100.51 \\
& C-6 & B-6 & & & 500.33 & 100.07 \\
\hline Amoxicillin & C-1 & B-1 & 500 & $462.5-550 \mathrm{mg} / \mathrm{Tab}$ & 467.98 & 93.60 \\
& C-2 & B-2 & & $(92.5-110 \%)$ & 487.5 & 97.50 \\
& C-3 & B-3 & & & 500.7 & 100.14 \\
& C-4 & B-4 & & & 476.96 & 95.39 \\
\hline
\end{tabular}




\begin{tabular}{lcccccc}
\hline Cefixime & C-1 & B-1 & 200 & $184.5-220 \mathrm{mg} / \mathrm{Tab}$ & 153.78 & 76.89 \\
& C-2 & B-2 & & $(92.25-110 \%)$ & 201.4 & 100.70 \\
\cline { 2 - 3 } & C-3 & B-3 & & & 189.5 & 94.75 \\
& C-4 & B-4 & & & 194.8 & 97.40 \\
& C-5 & B-5 & & & 205.58 & 102.79 \\
& C-6 & B-6 & & & 209 & 104.50 \\
& C-7 & B-7 & & & 197.9 & 98.95 \\
\hline \multirow{5}{*}{ Cefuroxime } & C-1 & B-1 & 250 & $225-275 \mathrm{mg} / \mathrm{Tab}$ & 230.3 & 92.12 \\
& C-2 & B-2 & & $(90-110 \%)$ & 250.5 & 100.20 \\
& C-3 & B-3 & & & 256.2 & 102.48 \\
& C-4 & B-4 & & & 251.6 & 100.64 \\
& C-5 & B-5 & & & 239.4 & 95.76 \\
\hline Moxifloxacin & C-1 & B-1 & 400 & $380-420 \mathrm{mg} / \mathrm{Tab}$ & 401.5 & 100.34 \\
& C-2 & B-2 & & $(95-105 \%)$ & 403.5 & 100.88 \\
& C-3 & B-3 & & & 385.49 & 96.37 \\
& C-4 & B-4 & & & 280.2 & 70.05 \\
\hline
\end{tabular}

Table 5. Percentage of drug release pattern.

\begin{tabular}{|c|c|c|c|c|c|}
\hline Generic & Company & Brand & $\begin{array}{l}\text { Strength } \\
(\mathrm{mg})\end{array}$ & $\begin{array}{l}\text { Tolerance } \\
\text { (USP) }\end{array}$ & $\begin{array}{l}\text { Result } \\
(\%)\end{array}$ \\
\hline \multirow[t]{4}{*}{ Azithromycin } & $\mathrm{C}-1$ & B-1 & \multirow[t]{4}{*}{500} & \multirow{4}{*}{$\begin{array}{l}\text { Not less than } 80 \% \\
\text { in } 30 \mathrm{~min}\end{array}$} & $101-103$ \\
\hline & $\mathrm{C}-2$ & B-2 & & & $97-100$ \\
\hline & $\mathrm{C}-3$ & B-3 & & & $97-101$ \\
\hline & C-4 & B-4 & & & $92-98$ \\
\hline \multirow[t]{6}{*}{ Ciprofloxacin } & $\mathrm{C}-1$ & B-1 & \multirow[t]{6}{*}{500} & \multirow{6}{*}{$\begin{array}{l}\text { Not less than } 80 \% \\
\text { in } 30 \mathrm{~min}\end{array}$} & $99-100$ \\
\hline & $\mathrm{C}-2$ & B-2 & & & $93-101$ \\
\hline & $\mathrm{C}-3$ & B-3 & & & $90-97$ \\
\hline & C-4 & B-4 & & & $20-43$ \\
\hline & C-5 & B-5 & & & $97-102$ \\
\hline & C-6 & B-6 & & & $85-103$ \\
\hline \multirow[t]{4}{*}{ Amoxicillin } & $\mathrm{C}-1$ & B-1 & \multirow[t]{4}{*}{500} & \multirow{4}{*}{$\begin{array}{l}\text { Not less than } 80 \% \\
\text { in } 60 \mathrm{~min}\end{array}$} & $82-96$ \\
\hline & $\mathrm{C}-2$ & B-2 & & & $91-101$ \\
\hline & C-3 & B-3 & & & $97-102$ \\
\hline & C-4 & B-4 & & & $93-99$ \\
\hline \multirow{6}{*}{ Cefixime } & $\mathrm{C}-1$ & B-1 & \multirow[t]{6}{*}{200} & \multirow{6}{*}{$\begin{array}{l}\text { Not less than } 75 \% \\
\text { in } 45 \mathrm{~min}\end{array}$} & $82-98$ \\
\hline & $\mathrm{C}-2$ & B-2 & & & $81-96$ \\
\hline & $\mathrm{C}-3$ & B-3 & & & $93-96$ \\
\hline & $\mathrm{C}-4$ & B-4 & & & $45-56$ \\
\hline & C-5 & B-5 & & & $99-103$ \\
\hline & C-6 & B-6 & & & $98-103$ \\
\hline \multirow{5}{*}{ Cefuroxime } & $\mathrm{C}-1$ & B-1 & 250 & \multirow{5}{*}{$\begin{array}{l}\text { Not less than } 65 \% \\
\text { in } 15 \text { min, } \\
\text { Not less than } 80 \% \\
\text { in } 45 \text { min }\end{array}$} & $92-97$ \\
\hline & & & & & $100-104$ \\
\hline & $\mathrm{C}-2$ & B-2 & & & $\begin{array}{l}77-81 \\
99-106\end{array}$ \\
\hline & C-3 & B-3 & & & $\begin{array}{l}88-93 \\
97-104\end{array}$ \\
\hline & C-4 & B-4 & & & $\begin{array}{l}76-95 \\
84-104\end{array}$ \\
\hline \multirow{4}{*}{ Moxifloxacin } & $\mathrm{C}-1$ & B-1 & 400 & \multirow{4}{*}{$\begin{array}{l}\text { Not less than } 75 \% \\
\text { in } 45 \mathrm{~min}\end{array}$} & $97-100$ \\
\hline & $\mathrm{C}-2$ & B-2 & & & $93-98$ \\
\hline & $\mathrm{C}-3$ & B-3 & & & $92-98$ \\
\hline & C-4 & B-4 & & & $103-105$ \\
\hline
\end{tabular}


Table 6. A patient-oriented question-based survey on 300 respondents for determining the antibiotic using pattern among the patients.

\begin{tabular}{|c|c|c|c|c|c|c|c|}
\hline Questions & \multicolumn{7}{|c|}{ Answers } \\
\hline $\begin{array}{l}\text { Are you taking any } \\
\text { antibiotic now or have } \\
\text { taken antibiotic recently? }\end{array}$ & \multirow{2}{*}{\multicolumn{2}{|c|}{$\begin{array}{l}\text { Yes } \\
(76 \%) \\
\text { Lower } \\
\text { Respiratory } \\
\text { Tract Infection } \\
(18 \%)\end{array}$}} & \multicolumn{2}{|c|}{$\begin{array}{c}\text { No } \\
(12 \%)\end{array}$} & \multicolumn{3}{|c|}{$\begin{array}{l}\text { Prefer not to say } \\
\qquad(12 \%)\end{array}$} \\
\hline $\begin{array}{l}\text { What is/ was the reason } \\
\text { for you to take } \\
\text { antibiotic? }\end{array}$ & & & $\begin{array}{l}\text { Upper } \\
\text { Respiratory } \\
\text { Tract Infection } \\
(15 \%)\end{array}$ & $\begin{array}{l}\text { Pneumonia } \\
(3 \%)\end{array}$ & $\begin{array}{l}\text { Abdominal } \\
\text { Pain } \\
(5 \%)\end{array}$ & $\begin{array}{l}\text { Urinary Tract } \\
\text { Infection } \\
(15 \%)\end{array}$ & $\begin{array}{l}\text { Common } \\
\text { cold and } \\
\text { cough } \\
(17 \%)\end{array}$ \\
\hline $\begin{array}{l}\text { For how long have you } \\
\text { been or had taken the } \\
\text { antibiotic? }\end{array}$ & & $\begin{array}{l}\text { 1-3 Days } \\
(18 \%)\end{array}$ & & $\begin{array}{l}\text { 4-7 days } \\
(64 \%)\end{array}$ & & & $\begin{array}{l}>7 \text { days } \\
(18 \%)\end{array}$ \\
\hline $\begin{array}{l}\text { Which antibiotic are you } \\
\text { taking/was prescribed to } \\
\text { you? }\end{array}$ & $\begin{array}{l}\text { Cefixime } \\
(25 \%)\end{array}$ & $\begin{array}{l}\text { Cefuroxime } \\
\text { /Clavulanic } \\
\text { combination } \\
(33 \%)\end{array}$ & $\begin{array}{l}\text { Azithromycin } \\
(22 \%)\end{array}$ & $\begin{array}{l}\text { Amoxicillin } \\
(3 \%)\end{array}$ & $\begin{array}{l}\text { Flucloxa- } \\
\text { cillin } \\
(6 \%)\end{array}$ & $\begin{array}{l}\text { Ciprofloxacin } \\
(6 \%)\end{array}$ & $\begin{array}{l}\text { Moxifloxacin } \\
(5 \%)\end{array}$ \\
\hline $\begin{array}{l}\text { Did you complete/are } \\
\text { you planning to } \\
\text { complete the dosage } \\
\text { regimen/ } \\
\text { guideline? }\end{array}$ & & $\begin{array}{l}\text { Yes } \\
(18 \%)\end{array}$ & & $\begin{array}{l}\text { No } \\
(82 \%)\end{array}$ & & & $\begin{array}{l}\text { Prefer not to } \\
\text { say }(0 \%)\end{array}$ \\
\hline $\begin{array}{l}\text { If no, then what is/was } \\
\text { the reason behind } \\
\text { discontinuation of the } \\
\text { therapy? }\end{array}$ & & $\begin{array}{l}\text { Carelessness } \\
(49 \%\end{array}$ & & $\begin{array}{l}\text { Sense of } \\
\text { wellness } \\
(36 \%)\end{array}$ & & & $\begin{array}{l}\text { Cost of } \\
\text { medication } \\
(15 \%)\end{array}$ \\
\hline $\begin{array}{l}\text { Did you visit the } \\
\text { physician before } \\
\text { discontinuation of the } \\
\text { therapy? }\end{array}$ & & Yes $(22 \%)$ & & $\begin{array}{l}\text { No } \\
(78 \%)\end{array}$ & & & $\begin{array}{l}\text { Prefer not to } \\
\text { say } \\
(0 \%)\end{array}$ \\
\hline
\end{tabular}

In this segment of the study, products from various pharmaceutical companies were included. This included top-selling pharmaceutical companies as well as which do not have sufficient sale according to the Intercontinental Marketing Services (IMS) data base. However, it seems that regardless of the company's market value they are providing quality products into the market. Hence, the product quality should not be attributed to the rise in antibiotic resistance in the country.

A patient-oriented survey was conducted to understand the reasons that may contribute to the raise antibiotic resistance. Questions were designed to determine which antibiotics were most commonly taken by the surveyed patients, how many patients adhered to the physician's guidelines, and why some patients became incompliant (Table 6).

The first question was regarding the cause of antibiotic use. The patients described the condition for which he or she was taking the antibiotic. They were allowed to give one answer only. Among the 300 respondents $27 \%$ answered the cause as fever, $18 \%$ answered lower respiratory infection, $17 \%$ answered common cold and cough, 15\% upper respiratory tract infection and the other answers were urinary tract infection, abdominal pain and pneumonia (Table 7).

Then, the patients were asked about which antibiotic was being taken by him/her. The patient was allowed to answer as many antibiotics as he/she was taking. Thus, the total numbers of responses were greater than the total number of respondents. About 33\% responses were positive to cefuroxime/clavulanic acid combination, $25 \%$ to cefixime, $22 \%$ to azithromycin and the other antibiotics were flucloxacillin, ciprofloxacin. moxifloxacin and amoxicillin (Table 8). 
Next question was about the compliance of patients with the dosage regimen recommended by the prescribing physician. This was a yes/no question. Here, $18 \%$ respondents among 300 patients agreed that they continued their prescribed treatment whereas $82 \%$ discontinued the medications. For the incompliant patients, next question was why they became incompliant. Patients were allowed to cite more than one reason but in the surveyed sample, all individuals cited only one reason. Unbelievably, $49 \%$ of the respondents discontinued their medications just because of their carelessness, 36\% thought they were cured and $15 \%$ discontinued due to financial constraints (Table 9 and 10).

Table 7. Patient's described indications for taking antibiotics.

\begin{tabular}{lcc}
\hline Indications & Number of respondents & Percentage $(\%)$ \\
\hline Fever & 81 & 27 \\
Lower respiratory tract infection (LRTI) & 54 & 18 \\
Common cold and cough & 51 & 17 \\
Upper respiratory tract infection (URTI) & 45 & 15 \\
Urinary tract infection (UTI) & 45 & 15 \\
Abdominal pain & 15 & 5 \\
Pneumonia & 9 & 3 \\
\hline
\end{tabular}

Table 8. Generic name of the antibiotics being taken by patients.

\begin{tabular}{lcc}
\hline Antibiotic & Number of responses & Percentage $(\%)$ \\
\hline Cefuroxime + Clavulanic & 112 & 33 \\
Cefixime & 85 & 25 \\
Azithromycin & 75 & 22 \\
Flucloxacillin & 20 & 6 \\
Ciprofloxacin & 20 & 6 \\
Moxifloxacin & 18 & 5 \\
Amoxicillin & 8 & 2 \\
\hline
\end{tabular}

Table 9. Patient compliance with the physician's therapy.

\begin{tabular}{lcc}
\hline Condition & Number of patients & Percentage $(\%)$ \\
\hline Continued & 55 & 18 \\
Discontinued & 245 & 82 \\
\hline
\end{tabular}

Table 10. Reasons behind discontinuation of antibiotics.

\begin{tabular}{lcc}
\hline Reasons & Number of respondents & Percentage (\%) \\
\hline Carelessness & 147 & 49 \\
Sense of cure & 108 & 36 \\
Cost of medication & 45 & 15 \\
\hline
\end{tabular}

The survey has provided some insightful data regarding the patient behavior in this country. Firstly, the data showed that a large number of patients are taking antibiotics for medical purposes that may not require any antibiotic at all. For example, $17 \%$ of the surveyed population responded that the reason for taking antibiotic was common cold and cough which is usually viral in nature and does not require or response to antibiotic therapy.
A massive segment of the surveyed individuals discontinued antibiotic therapy as prescribed to them (82\% of the respondents). This is an alarming number because it indicates that in our country antibiotic courses are rarely being completed. Incomplete antibiotic therapy is one of the factors for the development of antibiotic resistance. Therefore, this data may shine some light into the cause behind antibiotic resistance in the country. 
The main reason for discontinuation appears to be carelessness and a wrong sense of cure. Some of the respondents also cited the cost of antibiotics as a reason for discontinuing the drug. This is understandable from the prescription data shown above where it was seen that more than $60 \%$ of the antibiotic-containing prescriptions included expensive antibiotics though economic ones were available. In fact, it is possible that the cost of medicines actually had a greater hidden impact where the patient upon feeling better decided on his own not to continue the antibiotic treatment.

\section{CONCLUSION}

The present data shows that antibiotic resistance is prevalent in Bangladesh, at least for E. coli and $S$. aureus clinical isolates. The study showed that prescription practices of the physicians regarding antibiotics are less than optimal. The physicians appear to prescribe antibiotics when they are not necessary, and many of them used to prescribe broad-spectrum antibiotics or expensive antibiotics. The data also revealed that patient incompliance is overwhelming in our country regarding the completion of course of antibiotics. More than $80 \%$ are not completing the therapy due to various reasons such as carelessness, false sense of wellness, or high cost. Regarding product quality, regardless of the company's market share, the quality in terms of drug content and drug dissolution was within the acceptable range with only a few exceptions. Therefore, antibiotic product quality is standard and should not be associated with the development of antibiotic resistance. But this statement has limitations that we randomly tested antibiotic products of only a small number of companies (32 out of 162 operative companies).

\section{ACKNOWLEDGEMENTS}

The authors sincerely acknowledge the help of Biomedical Research Centre, University of Dhaka for using their laboratory facilities.

\section{REFERENCES}

1. Centres for Disease Control and Prevention. 2013. Antibiotic resistance threats in the United States. U.S. Dep. Health Hum. Serv. p. 11.

2. World Health Organization. 2007. Quality assurance of pharmaceuticals: A compendium of guidelines and related materials. Good manufacturing practices and inspection. WHO Tech. Rep. Ser. 2, 188-196.

3. O'Neill, J. 2014. Antimicrobial resistance: tackling a crisis for the health and wealth of nations. Rev. Antimicrob. Resist. 20, 1-16.

4. Bbosa, G.S., Mwebaza, N., Odda, J., Kyegombe, D.B. and Ntale, M. 2014. Antibiotics/antibacterial drug use, their marketing and promotion during the post-antibiotic golden age and their role in emergence of bacterial resistance. Health 6, 410-425.

5. Roy, J. 1997. Health status, treatment and drug use in rural Bangladesh: a case study of a village. Aust. J. Rural Health 5, 70-75.

6. Ahmed, S.M. and Hossain, M.A. 2007. Knowledge and practice of unqualified and semi-qualified allopathic providers in rural Bangladesh: implications for the $\mathrm{HRH}$ problem. Health Policy 84, 332-343.

7. Akter, F.U., Heller, D., Smith, A., Rahman, M.M. and Milly, A.F. 2004. Antimicrobial use in paediatric wards of teaching hospitals in Bangladesh. Mymensingh Med. J. 13, 63-66.

8. Ventola, C.L. 2015. The antibiotic resistance crisis: part 1: causes and threats. J. Clin. Pharm. Ther. 40, 277.

9. Faiz, M.A. and Basher, A. 2011. Antimicrobial resistance: Bangladesh experience. Reg. H. Forum. 15, 1-8.

10. Ronsmans, C., Islam, T. and Bennish, M.L. 1996. Medical practitioners' knowledge of dysentery treatment in Bangladesh. Br. Med. J. 313, 205-206.

11. Chowdhury, F.R., Rahman, M.M., Huq, M.F. and Begum, S. 2006. Rationality of drug uses: its Bangladeshi perspectives. Mymensingh Med. J. 15, 215-219.

12. Islam, M.S. 2006. A review on the policy and practices of therapeutic drug uses in Bangladesh. Calicut Med. J. 4, 2-4.

13. Biemer, J.J. 1973. Antimicrobial susceptibility testing by the Kirby-Bauer disc diffusion method. Ann. Clin. Lab. Sci. 3, 135-140.

14. United States Pharmacopoeial Convention. 2006. Board of Trustees, United States Pharmacopeial Convention, Committee of Revision and National Formulary Board. U.S. Pharmacopeia Natl. Formul. 